A.A. Gudaryan, I.S. Maschenko, A.S. Dorogina, S.V. Shyrinkin

\section{JUSTIFICATIONS FOR DIFFERENTIATED APPROACH IN CORRECTION OF SOME CHANGES OF THE IMMUNOLOGIC DISORDERS IN PATIENTS WITH RAPIDLY PROGRESSING GENERALIZED PARODONTITIS WITH DIFFERENT DRUG SUSCEPTIBILITY OF THE PARODONTAL BACTERIA}

\author{
SE «Dnipropetrovsk medical academy of Health Ministry of Ukraine» \\ Oral Surgery, implantology and Periodontology department \\ V. Vernadsky str., 9, Dnipro, 49044, Ukraine \\ Д3 «Дніпропетровська медична академія МОЗ України» \\ кафедра хірургічної стоматології, імплантологї̈ та пародонтології \\ (зав. - д. мед. н., дои. Н.Г. Ідашкіна) \\ вул. В. Вернадського, 9, Дніпро, 49044, Украӥна \\ e-mail: A.s.dorogina89@gmail.com
}

\footnotetext{
Цитування: Медичні перспективи. 2020. Т. 25, № 4. С. 138-146

Cited: Medicni perspektivi. 2020;25(4):138-146
}

Key words: rapidly progressive generalized periodontitis, infectious and inflammatory process, drug-resistant microflora, immunity

Ключові слова: швидкопрогресуючий генералізований пародонтит, інфекиійно-запальний процес, лікарськорезистентна мікрофлора, імунітет

Ключевые слова: быстропрогрессирующий генерализованный пародонтит, инфекционно-воспалительный процесс, лечебно-резистентная микрофлора, иммунитет

\begin{abstract}
Justifications for differentiated approach in correction of some changes of the immunologic disorders in patients with rapidly progressing generalized parodontitis with different drug susceptibility of the parodontal bacteria. Gudaryan A.A., Maschenko I.S., Dorogina A.S., Shyrinkin S.V. Rapidly progressing generalized periodontitis (RPGP) still remains an extremely important medical problem, despite certain achievements in solving most of the issues of etiology, pathogenesis and treatment. The study included 102 patients with rapidly progressing periodontitis of I-II and II-III degrees of severity, with ineffective and inconsistent results of previous treatment who were examined and treated in the clinic of the Department of Surgical Dentistry, Periodontics and Implantology of the SE «Dnipropetrovsk medical academy of Health Ministry of Ukraine». On the basis of the diagnostic and therapeutic measures carried out, it was established that, in patients with rapidly progressing generalized periodontitis, the formation of various drug sensitivity in periodontopathogenic microorganisms to protocol antibacterial therapy is closely associated with immunological protocol diseases. The presence of drug-resistant bacteria in the periodontal tissues is combined with a more pronounced immunodeficiency in the mechanisms of systemic and local protection than when the lesions are colonized by drug-sensitive periodontal microorganisms. The revealed features of immunity disorders in patients with RPGP with drug-resistant infection to conventional antibiotic therapy are manifested by a decrease in $C D_{3}+$ lymphocytes, cells with cytostatic activity $\left(C D_{4}+, C D_{16}+\right)$ expressing receptors for the activation of lymphocytes $C D_{25}+, H L A-D R$ and apoptosis $C D_{95}+$ ), against the background of a slight increase in $C D_{20^{+}}, C D_{116}+, C D_{54}+$, significant inhibition of the synthesis of SIgA, IgM, $\alpha-I N F, \gamma-I N F ;$ a pronounced increase in the production of proinflammatory cytokines $I L-1 \beta$ and $T N F-\alpha$. The need for a differentiated approach in the correction of immunological disorders in patients with RPGP depending on the detected sensitivity and resistance of periodontal pathogenic bacteria to the protocol generally accepted antibacterial therapy has been clearly proved; this provides a faster relief of the infectious and inflammatory process (on average on $3.6 \pm 0.2$ day) in more than $90 \%$ of cases, normalization of the parameters of immunological reactivity in $93.3 \%$ of the observed and stable clinical remission of the disease.
\end{abstract}

Реферат. Обгрунтування диференційованого підходу в корекції деяких змін імунологічних розладів у хворих на швидкопрогресуючий генералізований пародонтит 3 різною лікарською чутливістю пародонтальних бактерій. Гудар'ян О.О., Мащенко І.С., Дорогіна О.С., Ширінкін С.В. Швидкопрогресуючий генералізований пародонтит, як і раніше, залишається надзвичайно важливою медичною проблемою, незважаючи на певні досягнення у вирішенні більшості питань етіології, патогенезу та лікування. У дослідження було включено 102 хворих на швидкопрогресуючий генералізований пародонтит I-II $і$ II-III ступенів 
тяжкості, з малоефективними і нестійкими результатами проведеного раніше лікування, які перебували на обстеженні та лікуванні в клінічі кафедри хірургічної стоматології, імплантологї та пародонтологї дЗ «Дніпропетровська медична академія МОЗ Украӥни». На підставі проведених діагностичних $і$ лікувальних заходів встановлено, щчо у хворих формування різної лікарської чутливості в пародонтопатогенних мікроорганізмів до протокольної антибактеріальної терапї тісно пов'язане з імунологічними захворюваннями. Наявність у тканинах пародонта лікарсько-резистентних бактерій поєднується з більш вираженим імунодефіцитом у механізмах системного й локального захисту, ніж при заселенні осередків ураження лікарсько-чутливими пародонтальними мікроорганізмами. Виявлені особливості порушень імунітету у хворих на швидкопрогресуючий генералізований пародонтит з лікарсько-резистентною інфекцією до загальноприйнятої антибактеріальної терапії проявляються зниженням $\mathrm{CD}_{3}+$ лімфочитів, клітин з цитостатичною активністю $\left(\mathrm{CD}_{4}+, C D_{16}+\right)$, щзо експресують рецептори активаџіï лімфоцитів $C_{25}+$, HLA-DR $i$ aпоптозу $\left.C D_{95}+\right)$, на тлі деякого підвищення $C D_{20}+, C D_{116}+, C D_{54}+$, значним пригніченням синтезу $\operatorname{SIgA,~} \operatorname{Ig} M, \alpha-I H \Phi, \gamma-$ IНФ; вираженим підвищенням продукиії прозапальних ичитокінів IЛ-1 $і$ ФНП- $\alpha$. Наочно доведена необхідність диференційованого підходу в корекиії імунологічних розладів у хворих на швидкопрогресуючий генералізований пародонтит залежно від виявлення чутливості $i$ резистентності пародонтопатогенних бактерій до протокольної загальноприйнятої антибактеріальної терапії, що забезпечує більш швидке переривання

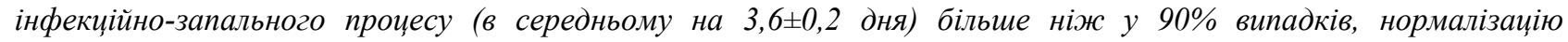
параметрів імунологічної реактивності в 93,3\% спостережуваних і стійку клінічну ремісію захворювання.

In spite of the seeming decisions for most issues of the etiology, pathogenesis and treatment, rapidly progressing generalized parodontitis (RPGP) still remains an extremely important medical problem associated with a variety of complex tasks and controversial points, which can appear in this pathology and which need a rethinked approach $[4,10,11]$.

Now, the only way for the etiotropic treatment of the patients with the rapidly progressive generalized parodontitis with the proven efficiency is the application of antibiotics. However, the experience of many years of the specialists and of the literature data certifies, that an empiric and multiple application of the whole range of antibiotics, included in the multimodality therapy protocol, can lead to the change not only of the microflora's character in the alveolar tissues, but also to promote the drug resistance development to the applicable drugs and to the immune deficiency states. $[5,6,9]$

In that situation, the antibiotic therapy, according to the generally accepted protocol schemes, can be not very effective, what determines the further chronization of the inflammatory process in the parodontium and the acceleration of the destructive phenomena in the alveolar tissues, the occurrence of the frequent relapses of active inflammation and the formation of severe variants of generalized parodontitis $[2,7]$.

It is known, that immunodeficiency states of the local and general immune protection are fundamental in the generalization of the infectiousinflammatory and destructive process in the periodontal complex and in the development of the severe forms of the generalized parodontitis course $[3,8]$.

The matters of choice of suitable immunocorrectors in the integrated treatment of the rapidly progressing parodontitis with different drug susceptibility of bacterial pathogens remain difficult and not fully studied, what takes on special significance in the differentiated therapeutic support of such patients.

Taking into account, that one of the key mechanisms in the pathogenesis of development of different drug susceptibility are immunologic disorders of the systemic and local antibody mediated immunity [10], the essential value obtains the dynamic control of immune alterations in process of the complex therapy in the long date after its termination.

All of the above justifies the development of technologies for a differentiated approach in the choice of the necessary correction of immune alterations in patients with the rapidly progressing parodontitis with different drug susceptibility of the parodontal bacteria to the protocol antibacterial therapy, this served as a motive to execute this work and to determine the goal of researches.

Aim of the researche is to improve the quality of the integrated treatment of the rapidly progressive generalized parodontitis in the conditions of the alveolar tissues colonization with the dominant pathogens of disease with different susceptibility to the common protocol therapy.

\section{MATERIALS AND METHODS OF RESEARCH}

The research included 102 patients with a rapidly progressing parodontitis of the I-II and II-III severity levels, who were examined and treated in the clinic in the department of surgical dentistry, periodontology and implantology of the State Institution "Dnipropetrovsk Medical Academy of the Ministry of Health of Ukraine". There were 56 (55\%) women and $46(45 \%)$ men in the age from 35 to 50 years (the average age $-34.6 \pm 1.4$ years).

The diagnosis verification was conducted according to the criteria, presented in the classification of I.S. Mashchenko (2003) and in the international classification ICD-10. 
The control group was composed of 24 practically healthy donors-volunteers in the age from 35 to 50 years (the average age $-33.8 \pm 1.9$ years), who did not have pathologies of periodontal tissues, teeth and parodontium injuries.

The research included only the patients with the rapidly progressing generalized parodontitis with loweffective and not constant results of the previously conducted treatment who gave a written informed consent for examination and planning of the therapy measures.

General life history analyses did not detect the coexisting diseases requiring treatment at the moment of examination and the use of antibacterial medications in patients chosen for the in-depth examination.

There were studied general clinical and paraclinical signs and X-ray examination was carried out to receive objective information of the state of the alveolar tissues in patients with the RPGP.

The clinical examination included a detailed collection of complaints and anamnes, a visual and laboratory evaluation of the gingival tissues state, the presence of hyperemia, the degree of bleeding tendency severity of gingival oedema, the depth of the periodontal pockets were determined, their contents and teeth mobility was taken into account.

To conduct the objective characteristics of the state of the alveolar tissues in patients with RPGP, we used the data obtained with the use of the gingival and dental plaque indexes.

The state of oral hygiene in patients was estimated by the methodology of Green V.C. Vermillion (1964), the intensity of inflammatory process and the intensity of the bleeding tendency of the parodontium tissues by Muhlemann $\mathrm{H}$. Cowell (1975), the prevalence rate of inflammation with the papillary marginal alveolar index (PMA), modified by C. Parma in 1960. For objectification of the severity and prevalence rate of the inflammatory and destructive changes in the alveolar tissues, the dental plaque index (PI) by Russel (1956) was used [4].

The depth of the periodontal pockets was measured by the traditional way with Goldman-Fox catheter and according to the data of the graphical cards obtained during the examination of the parodontium tissues by the Florida Probe system.

To clarify the diagnosis and the degree of the destructive process in the osseous structures of parodontium, there was made a dental panoramic radiogram, in the case of necessity - a digital threedimensional computer dental tomography on the Planmeca Pro Max radial tomograph (Finland).

The results of the clinical and paraclinical studies in patients with the rapidly progressing generalized parodontitis were compared with the data received from 19 apparently healthy blood donors.

For revealing indicators of the shift of the immune system cellular component (nonspecific resistance system) there was conducted immunophenotypic analysis of the state of the subpopulation blood cells composition obtained at determining of the percentage composition of the total number of T-lymphocytes $\left(\mathrm{CD}_{3}+\right)$, number of T-lymphocytes helpers $\left(\mathrm{CD}_{4}+\right)$, number of cytostatic T-lymphocytes $\left(\mathrm{CD}_{8}+\right)$, of the total number of $\mathrm{B}$ lymphocytes $\left(\mathrm{CD}_{19}+\right)$, the content of EK $(\mathrm{CD} 16+)$, number of $\alpha$-chains of receptor for the neutrophil chemoattractant factor $2\left(\mathrm{CD}_{25}+\right)$, expressions of Fas-antigen on monocytes $\left(\mathrm{CD}_{95}+\right)$ and HLA-DR+ cells. The research of the number of the listed cells expressing the antigens was carried out on the fluorescence-based flow cytometry device with monoclonal antibodies of domestic manufacture.

The concentration of cytokines IL- $1 \beta$, TNF- $\alpha$, IL-4, INF- $\alpha$ and INF- $\gamma$ was identified by the enzyme-linked immunosorbent assay technique (ELISA) and it was used as the indicating enzyme of the horseradish peroxidase, with the use of testsystems "Protein contour" (city of Saint Petersburg) according to the attached instructions. The results were expressed in $\mathrm{pg} / \mathrm{ml}$.

There were detected the levels of concentration of the immunoglobulins SIgA, IgA, IgG and IgM in the oral liquid with the enzyme-linked immunosorbent assay technique with the use of Pro Con set of reagents. The received data were expressed in $\mathrm{g} / \mathrm{l}$.

The sensitivity determination of the main periodontopathogenic bacteria to the most widely used in the practical dentistry with antibacterial agents (lincomycin, metronidazole, benzylpenicillin, gentamycine, ampicillin, dioxycycline, erythromycin and Amoxiclav) revealed in the periodontal pockets was conducted with the cassette micromethod. The calculation of results was according to the availability or absence of the bacterial colonies together with the used medication.

The statistical processing of the received data was conducted with Microsoft Excel 2010 (license number 02260-018-0000106-48794) i Statistica 6.1 (serial number AGAR909E415822FA). program with determination of an average (M), standard arithmetic average (m), Student's criterion. The correlation analysis according to Pearson was carried out. To take $p<0,05$ as the confidence level of the statistical indicators [1].

\section{RESULTS AND DISCUSSION}

According to the results of research of sensibility of the periodontopathogenic flora of the alveolar tissues, conducted at the preliminary stage of 
observations, it was detected the suppression or absence at all of the drug susceptibility of bacteria, which are widely used in the protocol antibacterial therapy, in more than $70 \%$ of patients with rapidly progressive generalized parodontitis with unstable treatment findings. Therewith, the periodontopathogens showed themselves as unsusceptible to two and more medications at the same time.

In estimation of connection of the results of the conducted integrated treatment and of the different drug susceptibility of the separating periodontopathogenic bacteria, it was identified the availability of the direct correlation relationship of the unstable results of treatment of the rapidly progressive generalized parodontitis and of the colonization of the alveolar tissues unsusceptible to the protocol antimicrobial therapy $(\mathrm{r}=89 ; \mathrm{p}<0.05)$, and with the drug-sensitive periodontopathogens it was marked a highly significant reverse correlation relationship $(\mathrm{r}=82 ; \mathrm{p}<0.05)$ of the mentioned bacteria with a short-term disease remission.

Taking into account the abovementioned, it was made a further study of the character of functioning of the local and systemic immunity in patients with stable strains of the parodontal microorganisms to the standard antimicrobial therapy and in patients with highly sensitive bacteria to the traditional medications.

The integrated assessment of the state of immune mechanisms was conducted in patients of two groups, comparable by sexual and age-related principles and by the severity of manifestation of the inflammatory-destructive process in the parodontium, in addition to contamination in the alveolar tissues of drug-sensitive or drug-resistant precursors of disease to the protocol antibacterial therapy, which is a part of the integrated treatment.

The first group (comparison group) consisted of the patients (42 persons) with previous treatment favorable results (long-lasting remission), whose periodontopathogenic bacteria remained highly sensitive to all antibacterial agents, which were used in the integrated protocol treatment of the generalized periodontitis.

The second (principal) group consisted of 60 patients persons with the insufficient results of the previous integrated treatment of progressive generalized periodontitis with stable strains of the periodontopathogenic bacteria to the standard antibiotic treatment (lincomycin and metronidazole).

There are marked disorders of the regulatory relations, in the system of cellular anti-infectious defense, and the signs of a low-grade immune deficiency of the T-cellular immunity according to the received findings in patients with the rapidly progressive generalized parodontitis against the background of the selected drug-sensible parodontal bacteria to the protocol antibacterial treatment are registered.

On the contrary, in patients with the colonization of parodontium tissues with drug-resistant precursors of disease, the immunophenotypic panel of T-lymphocytes is characterized by a more significant, than in the previous group, decrease of $\mathrm{CD}_{3}+$ and cells with cytostatic activity $\left(\mathrm{CD}_{16}+, \mathrm{CD}_{8}+\right)$, expression of $\mathrm{CD}_{25}+, \mathrm{CD}_{116}+$ cells and apoptosis of $\mathrm{CD}_{95}+$, HLA-DR of molecules (Table 1), this testifies to the availability of the expressed depression of cellular factors of antimicrobial defense by the type of the secondary immunodeficiency in them (Table 1).

The conducted initial researches of the levels of the main immunoglobulins classes in the oral liquid allowed us to detect the presence of the associative relation of different sensitivity of periodontal infection to the standard antibacterial therapy with a certain change of indicators of the local antibody mediated immunity. This regularity is most clearly observed in patients with drug-resistant bacteria, in which there is identified the maximum decrease of SIgA and IgM products in comparison with the parameters of the control group (by 3.9 and 2.6 times, respectively). In addition, within this framework, there was identified the tendency to decrease of IgG and IgA concentration levels only, this indicated the insufficiency of the compensatory response of the local immune anti-infectious defense in the analyzed group under study, most probably, to the antigenic bacterial stimulation: an increase of IgA and $\operatorname{IgG}$ synthesis by $17.6 \%$ and by $18.2 \%$ was noted (Table 1).

By contrast with the patients with the identified drug-sensitive periodontal causative agents, the immunoglobulin products of the main classes (with the exception of SIgA) turned out to be significantly higher than that obtained in the control group, and the synthesis of SIgA decreased only in 2.27 times.

When examining the interferon status. it was detected the impairment of the ability of leucocytes in patients with the rapidly progressing generalized parodontitis to the spontaneous production of INF- $\alpha$ and INF- $\gamma$ in the representatives of both groups. The lowest values of the mentioned cytokines were marked by colonization of the alveolar tissues with drug-resistant periodontopathogens (respectively. interferon- $\alpha$ by $49.6 \%$; interferon- $\gamma$ by $36.1 \%$ against the indicators - by $13.5 \%$ and $20.6 \%$ in patients with the drug-sensitive bacteria; $\mathrm{p}<0.05$ ).

At the same time. it was found that higher products of the pro-inflammatory cytokines (IL-1 $\beta$ and TNF- $\alpha$ ) and the reduction of the synthesis of anti-inflammatory cytokine IL-4 are more characteristic for patients with the rapidly progressing 
parodontitis, carriers of the drug-resistant types of parodontal infection and less significant products were found at colonization of the parodontium tissues and drug-resistant bacterial agents.

Table 1

The characteristics of the immune status in patients with rapidly progressing generalized parodontitis depending on the sensibility of the marked strains of the periodontopathogenic bacteria $(\mathrm{M} \pm \mathbf{m})$

\begin{tabular}{|c|c|c|c|}
\hline \multirow{2}{*}{$\begin{array}{l}\text { Systemic immunity } \\
\text { indicators }\end{array}$} & \multirow{2}{*}{$\begin{array}{l}\text { Apparently healthy } \\
\text { persons }(n=24)\end{array}$} & \multicolumn{2}{|c|}{ Patients with the generalized periodontitis } \\
\hline & & $\begin{array}{l}\text { sensitive to the common } \\
\text { antibacterial therapy } \\
\qquad(n=42)\end{array}$ & $\begin{array}{l}\text { resistant to the common } \\
\text { antibacterial therapy } \\
\qquad(\mathrm{n}=60)\end{array}$ \\
\hline $\mathrm{CD}_{3}+(\%)$ & $54.9 \pm 1.1$ & $51.8 \pm 1.4$ & $47.8 \pm 0.6$ \\
\hline $\mathrm{CD}_{4}+(\%)$ & $39.8 \pm 0.9$ & $38.2 \pm 1.2$ & $34.7 \pm 0.5^{*}{ }_{* *}$ \\
\hline$C D_{8}+(\%)$ & $22.9 \pm 1.4$ & $20.3 \pm 0.8$ & $15.3 \pm 0.6^{*}{ }_{* *}$ \\
\hline$C D_{16}+(\%)$ & $13.0 \pm 0.8$ & $18.9 \pm 1.2 *$ & $16.1 \pm 0.4^{*}{ }_{* *}$ \\
\hline$C D_{25}+(\%)$ & $18.4 \pm 0.4$ & $12.1 \pm 0.4^{*}$ & $5.36 \pm 0.2_{* * *}^{*}$ \\
\hline$C D_{71}+(\%)$ & $4.06 \pm 0.4$ & $9.9 \pm 0.4 *$ & $15.4 \pm 0.7_{* * *}^{*}$ \\
\hline$C \mathrm{D}_{54}+(\%)$ & $30.4 \pm 0.6$ & $77.4 \pm 1.2 *$ & $98.2 \pm 0.6_{* *}^{*}$ \\
\hline$C D_{116}+(\%)$ & $21.0 \pm 0.3$ & $18.8 \pm 0.7$ & $12.1 \pm 0.4_{* * *}^{*}$ \\
\hline$C D_{95}+(\%)$ & $16.5 \pm 0.4$ & $14.2 \pm 0.6^{*}$ & $7.0 \pm 0.2^{*}$ ** \\
\hline HLA-DR+ (\%) & $7.4 \pm 0.2$ & $16.1 \pm 0.8^{*}$ & $14.2 \pm 0.3_{* *}^{*}$ \\
\hline $\operatorname{SIgA~(Г/л)~}$ & $1.48 \pm 0.2$ & $0.65 \pm 0.03^{*}$ & $0.36 \pm 0.02^{*}{ }_{* *}$ \\
\hline $\operatorname{Ig} \mathbf{A}(g / \mathbf{l})$ & $0.61 \pm 0.03$ & $0.82 \pm 0.02^{*}$ & $0.74 \pm 0.02^{* * *}$ \\
\hline $\operatorname{IgG}(\mathrm{g} / \mathrm{l})$ & $10.8 \pm 0.3$ & $12.1 \pm 0.4^{*}$ & $13.2 \pm 0.3_{* * *}^{*}$ \\
\hline $\operatorname{IgM}(g / l)$ & $0.51 \pm 0.02$ & $1.08 \pm 0.61$ & $0.22 \pm 0.01^{*} * *$ \\
\hline$\alpha-$ INF (pg/ml) & $13.4 \pm 0.9$ & $20.6 \pm 0.4^{*}$ & $8.6 \pm 0.2^{*}$ ** \\
\hline$\gamma-\operatorname{INF}(\mathrm{pg} / \mathrm{ml})$ & $27.8 \pm 1.9$ & $22.7 \pm 1.6^{*}$ & $16.8 \pm 0.2_{* * *}^{*}$ \\
\hline IL -1ß(pg/ml) & $70.9 \pm 3.4$ & $199 \pm 6.2^{*}$ & $470.1 \pm 4.12^{*}{ }_{* *}$ \\
\hline TNF- $\alpha(\mathrm{pg} / \mathrm{ml})$ & $44.3 \pm 3.1$ & $103.9 \pm 4.0^{*}$ & $207.8 \pm 6.0^{*}{ }_{* * *}$ \\
\hline IL-4 (pg/ml) & $82.8 \pm 6.4$ & $49.6 \pm 5.1^{*}$ & $25.4 \pm 5.8_{* *}^{*}$ \\
\hline
\end{tabular}

Notes: ${ }^{*} \mathrm{p}<0.05$ is in regard to the standard values, ${ }^{* *} \mathrm{p}<0.05$ is in regard to the group of drug-sensitive patients.

The expression levels of IL- $\beta$ and TNF- $\alpha$ in patients with the drug-resistant bacteria exceeded the normal values by 6.5 and 4.7 times and in drugsensitive patients only by 2.8 and 3.3 times.
The difference of levels of the local products of IL- $1 \beta$ and FNO- $\alpha$ in the analyzed patients indicates undoubtedly to the more expressed activity of the inflammatory-destructive process in parodontium in 
patients with bacteria. which are resistant to the standard antibacterial agents. used in the integrated treatment of the disease. It is characteristic that the appearance in the periodontal ecological niche of the drug-resistant microorganisms and the intensification of the inflammatory process are accompanied by a sharp decrease of the products of antiinflammatory cytokine IL-4 (by 3.3 times respectively in comparison with the control values).

The suppression of synthesis of IL- 4 was lower in patients whose periodontal tissues were colonized by drug-sensitive periodontopathogens (by 1.7 times).

The received data confirm the necessity to search for the available immunocorrection methods for any clinic. differential and effective in the clinical aspect. which can maximally eliminate the available immune system disorders in patients with the RPGP. depending on the drug- susceptibility of the periodontopathogenic flora. which colonizes the alveolar tissues. to the protocol antibacterial agents.

As different immunomodulators affect pharmacologically the immune system in a different manner. and including the fact that in our study it was found that the disorders of immunological reactivity are as the determining factor of the course of inflammatory-destructive process in the alveolar tissues and can also influence the sensibility of the causative agents of the rapidly progressing generalized parodontitis to the traditional anti-infective drugs. it was showed a certain interest to the further study of the corrective action of polyoxidonium. licopid and roncoleukin. prescribed for this pathology separately and in the form of combinations.

The first group includes 42 drug-sensitive patients and the II and the III groups (30 persons) include patients with the drug-resistant bacteria. which colonize the periodontal pockets. The polyoxidonium immunomodulator was prescribed to patients of the first and second group as an immunocorrective therapy with the doses and course of administration. which are recommended in the instructions.

The integrated treatment protocol. along with immunocorrection. also included the similar traditional antibacterial therapy: chlorhexidine-containing drugs in combination with antibiotic Amoxiclav in the III-rd group of patients; antibiotic lincomycin in representatives of the I and II groups according to the regulations. recommended by the manufacturers.

The estimation of the immediate results of the integrated treatment of the rapidly progressing parodontitis showed that the elimination of the inflammatory process was achieved in most of the studied persons from the first group (95.2\% cases) on the 6-7 day of treatment (in average on the $6.4 \pm 0.2$ day) and only in $60 \%$ of patients of the second group (in average on $3.6 \pm 0.2$ day). and in patients of the third group in $93.3 \%$ cases (in average on the $6.8 \pm 0.2$ day of treatment) a delay was not. It should be noted. that. simultaneously with the elimination of the inflammatory process in the alveolar tissues. the normalization of all gingival and dental plaque indexes was also marked. The paraclinical parameters in patients with the residual signs of inflammatory reactions in the gingival tissue had only a tendency to some decrease.

As it turned out. the higher effectiveness of treatment in patients of the I and III groups than in patients of the II group was mainly due to a higher degree of correction of immunological disorders in patients of these groups (Table 2).

Polyoxidonium exerted a great positive influence on the immunopathological mechanisms only in patients with the rapidly progressing parodontitis in the conditions of the initial colonization of alveolar tissues with the drug-susceptible microorganisms (the first group of patients).

Against the background of the drug-resistant periodontopathogenic flora in the periodontal pockets. its use in the protocol of the integrated treatment turned out to be insufficiently effective regarding elimination of deficiency of the humoral and cellular component of immune system (the second group of patients). Despite the positive dynamics of the analyzed indicators. in general after its use the normalization of the most of the studied immunological parameters was detected in less than $50 \%$ of cases. and in the other cases there were signs of moderate insufficiency of the immunological resistance.

It was found that the inclusion of the immunorehabilitation complex which includes polyoxidonium together with licopid or roncoleukin in the integrated therapy of patients with the rapidly progressing generalized periodontitis with drugresistant periodontal pathogenic bacteria in the alveolar tissues. ensured elimination of disorders of the immune response in $93.3 \%$.

In 3-6 months after the conducted treatment. the clinic-laboratorial results achieved in $90.3 \%$ of patients of the I and III groups were characterized with a stable stability. During this period of observation there were no cases of relapses of the infectious and inflammatory process. which was confirmed by the further dynamics of the gingival and periodontal indices. There was a decrease in the periodontal index by an average of more than 2 points and the depth of periodontal pockets was from $6.6 \pm 0.2$ to $3.2 \mathrm{~mm}$. The positive dynamics of parameters of cellular and local immunity was traced. 
Table 2

Dynamics of humoral and cellular immunity parameters in patients with rapidly progressing generalized parodontitis who received different immunomodulating agents $(\mathrm{M} \pm \mathrm{m})$

\begin{tabular}{|c|c|c|c|c|c|c|}
\hline \multirow{3}{*}{$\begin{array}{l}\text { Parameters of } \\
\text { immunity }\end{array}$} & \multicolumn{6}{|c|}{ Groups of the studied persons } \\
\hline & \multicolumn{2}{|c|}{$\begin{array}{l}\text { first group of patients. } \\
\text { on medication with polyoxidonium } \\
(n=40)\end{array}$} & \multicolumn{2}{|c|}{$\begin{array}{l}\text { second group of patients. } \\
\text { on medication with } \\
\text { polyoxidonium }(n=29)\end{array}$} & \multicolumn{2}{|c|}{$\begin{array}{l}\text { third group of patients. on medication } \\
\text { with polyoxidonium together with } \\
\text { licopid and roncoleukin }(n=30)\end{array}$} \\
\hline & before treatment & after treatment & $\begin{array}{l}\text { before } \\
\text { treatment }\end{array}$ & $\begin{array}{c}\text { after } \\
\text { treatment }\end{array}$ & $\begin{array}{c}\text { before } \\
\text { treatment }\end{array}$ & after treatment \\
\hline$C \mathrm{D}_{3}+(\%)$ & $51.6 \pm 1.2$ & $55.2 \pm 1.1^{* *}$ & $49.8 \pm 1.3^{*}$ & $50.8 \pm 1.2^{* *}$ & $46.8 \pm 1.2^{*}$ & $52.9 \pm 0.8^{* *}$ \\
\hline $\mathrm{C} \mathrm{D}_{4}+(\%)$ & $38.8 \pm 1.2$ & $40.3 \pm 0.8$ & $35.8 \pm 1.2$ & $34.7 \pm 1.2^{* *}$ & $36.1 \pm 0.9$ & $38.8 \pm 0.6^{* *}$ \\
\hline$C \mathrm{D}_{8}+(\%)$ & $20.3 \pm 0.8$ & $22.8 \pm 1.2$ & $16.1 \pm 0.4^{*}$ & $17.1 \pm 0.9^{* * *}$ & $16.4 \pm 0.5^{*}$ & $30.1 \pm 0.9^{* *}$ \\
\hline$C D_{16}+(\%)$ & $18.2 \pm 1.2$ & $13.2 \pm 0.7$ & $14.0 \pm 0.6$ & $13.4 \pm 0.6^{* * *}$ & $13.8 \pm 0.5$ & $13.2 \pm 0.5$ \\
\hline$C \mathrm{D}_{25}+(\%)$ & $12.4 \pm 0.4^{*}$ & $20.3 \pm 0.9^{* *}$ & $15.5 \pm 0.7^{*}$ & $16.9 \pm 0.9^{* *}$ & $15.2 \pm 0.6^{*}$ & $17.6 \pm 0.4^{* *}$ \\
\hline$C D_{71}+(\%)$ & $9.9 \pm 0.4^{*}$ & $4.2 \pm 0.2^{* *}$ & $2.9 \pm 0.3^{*}$ & $10.0 \pm 0.2^{* *}$ & $6.1 \pm 0.4^{*}$ & $14.2 \pm 0.4^{* *}$ \\
\hline $\mathrm{C} \mathrm{D}_{54}+(\%)$ & $74.5 \pm 1.2^{*}$ & $32.5 \pm 1.4^{* *}$ & $93.3 \pm 1.2^{*}$ & $60.2 \pm 1.1^{* *}$ & $94.2 \pm 1.2^{*}$ & $27.1 \pm 0.6^{* *}$ \\
\hline$C D_{116}+(\%)$ & $18.9 \pm 0.5$ & $22.4 \pm 0.6^{* *}$ & $12.6 \pm 0.4^{*}$ & $14.7 \pm 0.6^{* *}$ & $12.8 \pm 0.4^{*}$ & $18.3 \pm 0.4^{* *}$ \\
\hline$C D_{95}+(\%)$ & $14.0 \pm 0.5^{*}$ & $17.2 \pm 0.6^{* *}$ & $7.3 \pm 0.4^{*}$ & $10.8 \pm 0.3^{* *}$ & $7.7 \pm 0.4^{*}$ & $17.1 \pm 0.3^{* *}$ \\
\hline HLA-DR+ (\%) & $16.4 \pm 0.6^{*}$ & $8.2 \pm 0.2^{* *}$ & $18.8 \pm 0.5^{*}$ & $10.9 \pm 0.3^{* *}$ & $19.1 \pm 0.6^{*}$ & $7.8 \pm 0.3^{* *}$ \\
\hline $\operatorname{sIgA}(g / l)$ & $0.63 \pm 0.03^{*}$ & $1.45 \pm 0.03^{* *}$ & $0.35 \pm 0.03^{*}$ & $0.67 \pm 0.04$ ** & $0.37 \pm 0.03^{*}$ & $1.29 \pm 0.3^{* *}$ \\
\hline $\operatorname{IgA}(g / \mathbf{l})$ & $0.85 \pm 0.02^{*}$ & $0.59 \pm 0.03^{* * *}$ & $0.73 \pm 0.05^{*}$ & $0.65 \pm 0.033^{* *}$ & $0.75 \pm 0.05^{*}$ & $0.72 \pm 0.066^{* *}$ \\
\hline $\operatorname{IgG}(g / \mathbf{l})$ & $12.4 \pm 0.4^{*}$ & $12.0 \pm 0.4^{* *}$ & $12.2 \pm 0.6^{*}$ & $12.0 \pm 0.3^{* *}$ & $13.6 \pm 0.7^{*}$ & $11.1 \pm 0.4^{* *}$ \\
\hline $\operatorname{IgM}(\mathrm{g} / \mathrm{l})$ & $1.07 \pm 0.04^{*}$ & $0.38 \pm 0.03^{* *}$ & $0.23 \pm 0.02^{*}$ & $0.43 \pm 0.04^{* *}$ & $0.21 \pm 0.02^{*}$ & $0.67 \pm 0.02^{* *}$ \\
\hline$\alpha$-INF (pg/ml) & $10.8 \pm 1.8^{*}$ & $15.9 \pm 1.2^{* *}$ & $8.5 \pm 1.3^{*}$ & $10.1 \pm 0.7^{* *}$ & $8.7 \pm 0.3^{*}$ & $13.8 \pm 0.7^{* *}$ \\
\hline$\gamma$-INF(pg/ml) & $22.6 \pm 1.4^{*}$ & $28.3 \pm 2.4^{* *}$ & $17.0 \pm 1.15^{*}$ & $20.9 \pm 0.9^{* *}$ & $16.6 \pm 1.03^{*}$ & $32.4 \pm 1.2^{* *}$ \\
\hline
\end{tabular}

Notes: *- the difference is significant $(\mathrm{p}<0.05)$ when compared with the group of healthy persons, $* *$ - the difference is significant $(\mathrm{p}<0.05)$ when compared with the indicators before and after treatment.

\section{CONCLUSIONS}

1. The formation of different drug susceptibility of periodontopathogenic microorganisms to the protocol antibacterial therapy in patients with the rapidly progressing generalized parodontitis is closely related to the immunologic protocol diseases. The presence of drug-resistant bacteria in the periodontal tissues is combined with more expressed immune deficiency in the mechanisms of the system and local defense than in colonization of the affected areas with the drug sensitive periodontal microorganisms.
2. The features of immunity in patients with the rapidly progressing generalized parodontitis with the drug-resistant infection to the common antibacterial therapy is manifasted with the reduction of $\mathrm{CD} 3+$ lymphocytes. cells with cytostatic activity (C D4 + . CD16 +). expressing the receptors of lymphocytes activation (CD25 +. HLA-DR and apoptosis CD95+) against the background of some increase of CD20 +. $\mathrm{CD} 116+$. CD54 +. with the significant depression of synthesis of $\operatorname{sgA}$. IgM. $\alpha$-INF. $\gamma$-INF; expressed 
with the increase of the products of the proinflammatory cytokines IL- $1 \beta$ и TNF- $\alpha$.

3. A differentiated approach to the correction of immunological disorders in patients with the rapidly progressing generalized parodontitis depending on the detected sensitivity and resistance of periodontopathogenic bacteria to the protocol common antibacterial therapy. provides more fast arresting of the infectious and inflammatory process (in average on $3.6 \pm 0.2$ day). more than in $90 \%$. it provides the normalization of the parameters of immunological reactivity in $93.3 \%$ of the observed persons and the stable clinical remission of the disease.

Conflict of interests. The authors declare no conflict of interest.

\section{REFERENCES}

1. Antomonov M. [Mathematical processing and analysis of biomedical data]. 2nd ed. Kyiv: MIC «Medinform»; 2018;579. ISBN 978-966-409-202-6. Russian.

2. Elovikova TM. Gaisina EF. Prihodkin. [The use of antibacterial drugs for aggressive forms of periodontitis]. Problemy stomatologii. 2019;15(1):10-15. Russian. doi: https://doi.org/10.18481/2077-7566-2019-15-1-10-15.

3. Kopeckii IS. Pobozh'eva LV. Sheveljuk JuV. [Aggressive periodontitis: clinical and microbiological aspects of development]. Lechebnoe delo. 2019;1:7-13. doi: https://doi.org/10.24411/2071-5315-2019-12084.

Russian.

4. Leonova EV. [Aggressive periodontitis: characteristics. clinical picture. diagnostics. treatment algorithms]. Clinical observation. Medi izdatel'stvo. 2018;1(78):34-36. Russian.

5. Mashhenko IS. Gudaryan AA. Dorogina AS. [The reasons for the resistance of the main periodontal pathogens to antibiotic therapy in patients with rapidly progressive generalized periodontitis]. Visnik stomatology. 2013;4:35-41. Russian.

6. Abe FC. Bergamaschi CC. Figueiró MF. Lopes LC. Resistance profile to antimicrobial agents in the main circulating bacteria isolated from acute periodontal and endodontic infections in Latin America (MICROBEDENT): A systematic review protocol. Medicine (Baltimore). 2018 Nov;97(48):e13158. PMID: 30508894; PMCID: PMC6283129.

doi: https://doi.org/10.1097/MD.0000000000013158
7. Kulik EM. Thurnheer T. Karygianni L. Walter C. Sculean A. Eick S. Antibiotic Susceptibility Patterns of Aggregatibacter actinomycetemcomitans and Porphyromonas gingivalis Strains from Different Decades. Antibiotics (Basel). 2019 Dec 6;8(4):253. PMID: 31817588; PMCID: PMC6963212.

doi: https://doi.org/10.3390/antibiotics8040253

8. Invernici MM. Salvador SL. Silva PHF. Soares MSM. Casarin R. Palioto DB. Souza SLS. Taba M Jr. Novaes AB Jr. Furlaneto FAC. Messora MR. Effects of Bifidobacterium probiotic on the treatment of chronic periodontitis: A randomized clinical trial. J Clin Periodontol. 2018 Oct;45(10):1198-210. Epub 2018 Sep 24. PMID: 30076613; PMCID: PMC6221043. doi: https://doi.org/10.1111/jcpe.12995.

9. Haque M. Sartelli M. Haque SZ. Dental Infection and Resistance-Global Health Consequences. Dent J (Basel). 2019 Mar 1;7(1):22. PMID: 30823670; PMCID: PMC6473604.

doi: https://doi.org/10.3390/dj7010022

10. Könönen E. Gursoy M. Gursoy UK. Periodontitis: A Multifaceted Disease of Tooth-Supporting Tissues. J Clin Med. 2019 Jul 31;8(8):1135. PMID: 31370168; PMCID: PMC6723779.

doi: https://doi.org/10.3390/jem8081135

11. Kornman KS. Contemporary approaches for identifying individual risk for periodontitis. Periodontol 2000. 2018 Oct;78(1):12-29. PMID: 30198138. doi: https://doi.org/10.1111/prd.12234

\section{СПИСОК ЛІТЕРАТУРИ}

1. Антомонов М. Ю. Математическая обработка и анализ медико-биологических данных. 2-е изд. Киев: МИЦ «Мединформ». 2018. 579 с.

2. Еловикова Т. М. Гайсина Е. Ф.. Приходкин А. С. Применение антибактериальных препаратов при агрессивных формах пародонтита. Пробл. стоматологии. 2019. Т. 15. № 1. С. 10-15. DOI: https://doi.org/10.18481/2077-7566-2019-15-1-10-15

3. Копецкий И. С.. Побожьева Л. В.. Шевелюк Ю. В. Агрессивный пародонтит: клинические и микроби ологические аспекты развития. Леч. дело. 2019. № 1. C. 7-13.

DOI: https://doi.org/10.24411/2071-5315-2019-12084

4. Леонова Е. В. Агрессивный пародонтит: характеристика. клиника. диагностика. алгоритмы лече- ния. Клиническое наблюдение. Мед. издательство. 2018. Т. 78. № 1. С. 34-36.

5. Мащенко И. С.. Гударьян А. А.. Дорогина А. С. Причины устойчивости основных пародонтальных возбудителей к антибактериальной терапии у больных с быстропрогрессирующим генерализованным пародонтитом. Вісник стоматологии. 2013. № 4. С. 35-41.

6. Abe F. C.. Bergamaschi C. C.. Figueiró M. F.. Lopes L. C. Resistance profile to antimicrobial agents in the main circulating bacteria isolated from acute periodontal and endodontic infections in Latin America (MICROBE- DENT): A systematic review protocol. Medicine (Baltimore). 2018. Nov. (Vol. 97. No. 48). e13158. PMID: 30508894; PMCID: PMC6283129. DOI: https://doi.org/10.1097/MD.0000000000013158 
7. Antibiotic Susceptibility Patterns of Aggregatibacter actinomycetemcomitans and Porphyromonas gingivalis Strains from Different Decades / E. M. Kulik et al. Antibiotics (Basel). 2019. 6 Dec. (Vol. 8. No. 4). P. 253. PMID: 31817588; PMCID: PMC6963212. DOI: https://doi.org/10.3390/antibiotics8040253

8. Effects of Bifidobacterium probiotic on the treatment of chronic periodontitis: A randomized clinical trial / M. M. Invernici et al. J Clin Periodontol. 2018. Oct. (Vol. 45. No. 10). P. 1198-1210. Epub 2018 Sep 24. PMID: 30076613; PMCID: PMC6221043.

DOI: https://doi.org/10.1111/jcpe. 12995

9. Haque M.. Sartelli M.. Haque S. Z. Dental Infection and Resistance-Global Health Consequences. Dent
$J$ (Basel). 2019. 1 Mar. (Vol. $7 . \quad$ No. 1). P. 22. PMID: 30823670; PMCID: PMC6473604.

DOI: https://doi.org/10.3390/dj7010022

10. Könönen E.. Gursoy M.. Gursoy U. K. Periodontitis: A Multifaceted Disease of Tooth-Supporting Tissues. J Clin Med. 2019. 31 Jul. (Vol. 8. No. 8). P. 1135. PMID: 31370168; PMCID: PMC6723779.

DOI: https://doi.org/10.3390/jcm8081135

11. Kornman K. S. Contemporary approaches for identifying individual risk for periodontitis. $P e$ riodontol 2000. 2018. Oct. (Vol. 78. No. 1). P. 12-29. DOI: https://doi.org/10.1111/prd.12234

Стаття надійшла до редакції 16.09.2020 